\title{
Effectiveness of Monetary Policy on Money and Credit in Pakistan \\ Kashif Munir
}

\begin{abstract}
This paper analyzes the effectiveness of monetary policy on money and credit in Pakistan by using the data rich environment. FAVAR model is used which consists of 115 macroeconomic variable for the period 1992:01 to 2010:12. Results depict that after a positive shock in interest rate (discount rate), M0 and M1 do not show any significant response, while M2 shows an instantaneous decline and shows revival after 34 months. Credit to public sector enterprises and credit to private sector both decline after a positive shock in monetary policy but credit to private sector declines more than credit to public sector enterprises and M2. An increase in interest rate discourages private sector which leads to slowdown in the economic activities and creates pressure on prices to increase. In Pakistan, the adverse victim of monetary policy is credit to private sector, therefore policy should be tailored to consider the demands of credit by private sector. The policies should be made which provide the credit to private sector at a subsidized rate and the environment of investment should be promoted by the authorities in the country.
\end{abstract}

KEY WORDS:

Monetary Policy, Money, Credit, VAR, FAVAR.

JEL Classification: C32, E52

University of Central Punjab, Pakistan

\section{Introduction}

Primary goals of monetary policy in Pakistan are economic growth, controlling inflation, promoting private investment, keeping financial markets stable, and building foreign exchange reserves. However, money and credit are the lifeblood of an economy, specially the developing economies. A rise in interest rate increases the cost of holding money and credit, and demand for money and credit declines in the economy and reduces the economic activities. In case of Pakistan, discount rate (interest rate) is the direct instrument of monetary policy, while M2 is the targeted

Correspondence concerning this article should be addressed to: Kashif Munir, University of Central Punjab, Pakistan. Email:kashifmunirdr@gmail.com variable. GDP growth rate shows persistent decline in the previous decade (2000 to 2010) in Pakistan, while inflation was in two digits. Kamin et al. (1998) argued that financial markets especially in emerging and underdeveloped economies are so poorly developed that the quantity of credit and its price becomes an important instrument of monetary policy. The credit channel is an enhancement mechanism encompassing a set of factors amplifying and transmitting the interest rate effect, it is not an independent channel (Bernanke \& Gertler, 1995).

Credit to private sector is the engine of growth in developing countries but with the tightening of monetary policy, the credit to private sector squeezes. State Bank of Pakistan (SBP) has to control the double digit inflation at the cost of credit to private sector which 
has pushed the economy into stagflation in the last decade (Amjad et al., 2011). Endogenous changes in the external finance premium lead to increase the direct impact of monetary policy on interest rate. Mishkin (1995) argued that size of external finance premium reflects imperfections in the financial markets and affected by the agency problems. Bernanke and Gertler (1995) argued that there are two possible channels through which a central bank can influence the external finance premium in the credit market i.e. bank lending channel, and balance sheet channel.

According to Agha et al. (2005), bank lending is the most important channel of transmission in Pakistan. Moreover, Alam and Waheed (2006) found that monetary policy has real effects on the economy in the short run. Ahmad and Qayyum (2008) argued that investment function indicates that increase in government current spending and interest rate discourages private investment and similarly macroeconomic instability and uncertainty affect the private investment negatively. Credit channel is an important channel of monetary transmission mechanism in Pakistan.

To achieve the goals of monetary policy, a thorough understanding of the monetary transmission mechanism is essential. The objective of this study is to explore the impact of monetary policy on money and credit in Pakistan in a data rich environment. Money includes all types of money used in Pakistan i.e. M0: Reserve Money, M1: Narrow Money, and M2: Broad Money, while credit includes credit to public sector enterprises and credit to private sector to fully understand the transmission mechanism of monetary policy on money and credit in Pakistan. The main contribution of this study is that it measures the effectiveness of monetary policy on money and credit in a data rich environment, while this type of exercise has not been undertaken so far for Pakistan.

Rest of the paper is organized in the following ways. Section 2 described the previous literature. Descriptive statistics on money, prices and output in Pakistan from 1992 to 2010 is discussed in Section 3. Section 4 deals with methodology and data. The empirical results on the effects of monetary policy on money and credit are analyzed in section 5. Section 6 contains concluding remarks and policy recommendation.

\section{Literature Review}

The basic assumption of the interest rate channel is that financial markets are perfectly competitive and work efficiently. Kamin et al. (1998) argued that financial markets are so poorly developed especially in emerging and underdeveloped economies that the quantity of credit and its price became a significant tool of monetary policy. Credit channel is an enhancement mechanism covering a set of factors in transmitting and amplifying the interest rate effect, it is not an independent channel (Bernanke \& Gertler, 1995). External finance premium is the difference between funds raised internally and externally, the effects of monetary policy on interest rate are enhanced by endogenous changes in the external finance premium. Mishkin (1995) argued that size of the external finance premium is affected by the agency problems and reveals imperfections in the financial markets. Bernanke and Gertler (1995) reported that central bank in the credit market can influence the external finance premium through two possible channels i.e. bank lending channel and balance sheet channel.

According to Bernanke and Gertler (1995), the effect of policy made actions on the supply of bank credit is the focus of the bank lending channel. Kashyap and Stein (1994) argued that bank lending channel originated in the loanable fund theory (Roosa, 1951; Blinder \& Stiglitz, 1983), and the extension of the IS-LM model of Bernanke and Blinder (1988). According to Bernanke (1983), a severe financial slump converted into a prolonged depression in 192930 due to the cost of intermediation and increases in information asymmetry followed by credit squeeze on aggregate demand. Banks play a central role in the economy according to Gertler and Gilchrist (1993) not only through issuing liabilities, but also by means of creating assets whose near substitute does not exist.

The focus of balance sheet channel is on the impact of a change in monetary policy and effects on borrower's balance sheets and income statement as well as variables such as borrower's cash flow, net worth and liquid assets, it is also called as "broad credit channel" or "financial accelerator". Furthermore, in addition to firms, the balance sheet channel can also be applied to the consumer spending, where the ability of the borrower to obtain loans for consumption and investment is directly related to the external finance 
premium (Bernanke \& Gertler, 1995). Asymmetric information in the credit market leads to adverse selection and moral hazard problems (Bernanke \& Gertler, 1995; Mishkin, 1995).

According to Bernanke and Gertler (1995) and Kuttner and Mosser (2002), the information asymmetry in the credit market increases premiums and decreases investment which leads to a decline in output. Theoretical models of Bernanke and Gertler (1989), Bernanke et al. (1999), Greenwald and Stiglitz (1993), and Kiyotaki and Moore (1997) describe the amplification and transmission mechanism in a dynamic context in which minor monetary disturbances have real persistent effects. These theoretical models explain that investment is dependent on the value of collateral, after a monetary shock it can cause amplification and persistent real effects (Bean et al., 2002). Quantitatively balance sheet channel is stronger because it leads to differences in the firm's financial health and cost of capital.

VAR is considered as a standard method to measure the monetary policy (Sims, 1980; 1992; Bernanke \& Blinder, 1992). Low dimension is one of the major shortcoming of VAR model which means that variable that can be included in the VAR model is not too large (Bernanke et al., 2005; Senbet, 2008; Blaes, 2009). Bernanke et al. (2005) discussed that low dimensional VAR model causes at least three major problems; information set covered by variable in VAR/SVAR model is much less than the information available to policy makers that's why contaminated policy shocks prevail, secondly specific variable (e.g. IPI) is used to depict some theoretical constructs; and thirdly impulse response function can only be estimated for the variables which has included in the VAR/ SVAR model. Bernanke et al. (2005) proposed Factor Augmented Vector Autoregressive (FAVAR) model to solve the main shortcoming of the standard VAR. FAVAR model gives more accurate results as compared to simple VAR model (Bernanke et al., 2005; Lagana and Mountford, 2005; Shibamoto, 2007; Senbet, 2008; Soares, 2011; Kabundi and Ngwenya, 2011; Munir and Qayyum, 2014, Munir, 2018).

There are few studies which measure the effects of monetary policy in Pakistan, and specially, on money and credit. Agha et al. (2005) examined the channels of monetary policy as well as transmission mechanism of monetary policy in Pakistan from 1996 to 2004 by using VAR method. Results showed that most effective channel is bank lending channel in Pakistan. Alam and Waheed (2006) analyzed the association among sectoral output and monetary policy. Quarterly time series data of Pakistan had been used from 1973 to 2003 by using VAR model. Results showed that in short run monetary policy has real effects on the economy and the sectors which depend on bank loan are affected more by tightening of monetary policy.

Ahmad and Qayyum (2008) analyzed the impact of government spending and macroeconomic fluctuation on private fixed investment in services sector of Pakistan from 1972 to 2005.

Results depicted that interest rate and increase in government current spending lead to decrease in private investment, while private investment respond negatively to macroeconomic instability and volatility. Munir and Qayyum (2014) analyzed the association among monetary policy and macroeconomic variables in Pakistan. They found that FAVAR model is better than the standard VAR model and explain the effects of monetary policy which are consistent with theory. Munir (2018) analyzed the impact of monetary policy on output and prices in Pakistan at disaggregate level. Results showed that output and prices show strong heterogeneity in Pakistan, as well as in the short run monetary policy has real effects, while interest rate influences the prices negatively with heterogeneous effects. There are few studies on the effectiveness of the monetary policy on the money and credit in Pakistan. Therefore, it is essential to analyze the impact of monetary policy on money and credit in Pakistan in a data rich environment.

\section{Money, Output and Prices in Pakistan}

In 1990, financial sector and monetary policy regime undergo the considerable changes in Pakistan with major focus on the liberalization. Prior to 1990, State Bank of Pakistan (SBP) used to conduct monetary policy by applying mostly the direct instruments, while with the move towards the liberalized monetary regime the SBP began to use the indirect instruments. Since then, a number of policy changes had been done for indirect monetary management (SBP, 2002). Since 1990, various steps have been undertaken to strengthen and liberalize the banking sector, 
including privatization of commercial banks.

Table 1 provides basic statistics on actual and targeted GDP growth rate, M2 growth rate, and inflation from 1991 to 2010. During this phase, actual inflation touched its highest level (20.8 percent) in 2008-09, and remains in two digits from 1990-91 to 1996-97 and then gradually slow down and reach its lowest level (3.1) in 2002-03 and then again goes to two digits from 2007-08 to 2009-10. The actual inflation remains higher than the targeted inflation from 1990-91 to 1996-97, while from 1997-98 to 2002-03 the targeted inflation remains higher than the actual inflation and from 2003-04 to 2009-10 inflation goes unbridled and remains higher than the target. This inflation episode shows some interesting facts about the effectiveness of monetary policy. Initially monetary policy remains ineffective to control inflation then it achieves its goals and inflation remains under control and after 2003-04 it remains ineffective to curb the inflationary spiral in the economy and inflation touches its highest level ever (i.e. 20.8\%) in 2008-09.

Actual growth rate of GDP also touched its highest level in this phase (i.e. 9 percent) in 2004-05. The actual growth rate of GDP remains higher than the targeted growth rate of GDP in 1990-91 and 199192, while from 1992-93 to 2001-02 the targeted growth rate of GDP remains higher than the actual growth rate of GDP, except in 1995-96 and from 2002-03 to 2004-05 the actual growth rate of GDP remains higher than the targeted, while after 200405 it remains on a declining trend. This episode of GDP growth rate shows the effectiveness of policies in Pakistan, especially the monetary policy, which remains totally ineffective to achieve its goals. The question remains unanswered that why growth rate has persistently declined and inflation touched new heights, why monetary policy is not effective to either control inflation or to increase growth rate. Figure 1 is showing credit to private sector (billion Rs.),

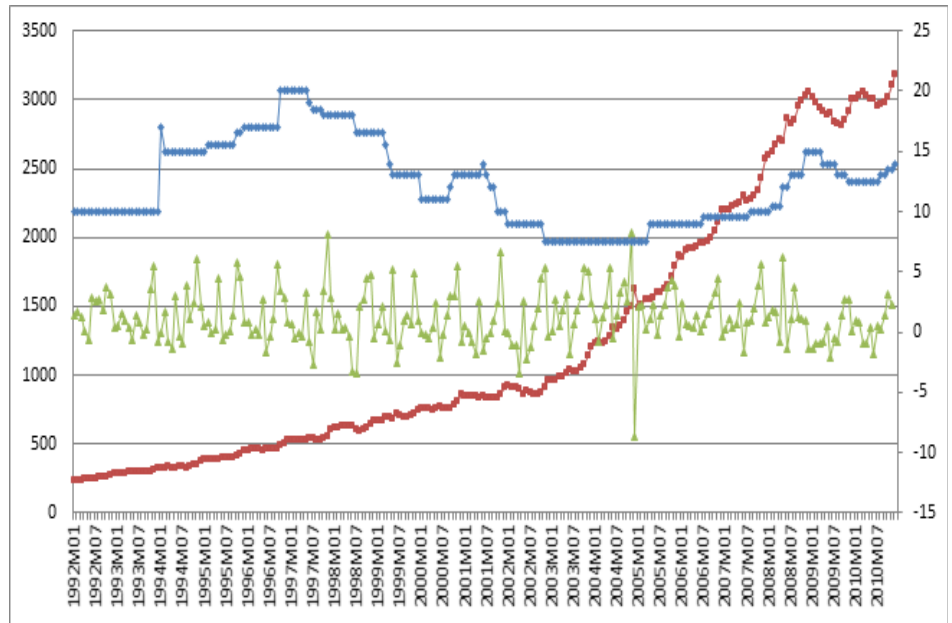

$\rightarrow$ Credit to Private Sector (billion Rs) $\longrightarrow$ Growth Rate of CPS $(\%) \rightarrow-$ Discount Rate (\% per annum)

Figure 1. Credit to private sector (level \& growth) and discount rate (1992-2010). 
Table 1. Actual and Targeted Growth Rate of Money, Output and Prices (1991-2010)

\begin{tabular}{|c|c|c|c|c|c|c|}
\hline \multirow[t]{2}{*}{ Year } & \multicolumn{2}{|c|}{ M2 Growth Rate } & \multicolumn{2}{|c|}{ GDP Growth Rate } & \multicolumn{2}{|c|}{ Inflation } \\
\hline & Actual & Target & Actual & Target & Actual & Target \\
\hline 1990-91 & 17.4 & 10.8 & 5.6 & 5.5 & 12.7 & 13 \\
\hline $1991-92$ & 26.2 & 12.9 & 7.7 & 6.7 & 10.6 & 7 \\
\hline $1992-93$ & 17.8 & 9.2 & 2.3 & 6.2 & 9.8 & 9.5 \\
\hline $1993-94$ & 18.1 & 14.03 & 4.5 & 7.5 & 11.3 & 7 \\
\hline $1994-95$ & 17.2 & 11.15 & 4.1 & 6.9 & 13 & 7 \\
\hline $1995-96$ & 13.8 & 13 & 6.6 & 6.5 & 10.8 & 9.5 \\
\hline $1996-97$ & 12.2 & 12.36 & 1.7 & 6.3 & 11.8 & 8.5 \\
\hline $1997-98$ & 14.5 & 14.24 & 3.5 & 6 & 7.8 & 9 \\
\hline $1998-99$ & 6.2 & 13.64 & 4.2 & 6 & 5.7 & 8 \\
\hline 1999-00 & 9.4 & 9.44 & 3.9 & 5 & 3.6 & 8 \\
\hline $2000-01$ & 9 & 10.5 & 2.9 & 5 & 4.4 & 4.5 \\
\hline 2001-02 & 15.4 & 9.5 & 3.1 & 4 & 3.5 & 5 \\
\hline $2002-03$ & 18 & 10.8 & 4.7 & 4.5 & 3.1 & 4 \\
\hline 2003-04 & 19.6 & 11.1 & 7.5 & 5.3 & 4.6 & 4 \\
\hline $2004-05$ & 19.3 & 11.3 & 9 & 6.6 & 9.3 & 5 \\
\hline $2005-06$ & 15.2 & 12.8 & 5.8 & 7 & 7.9 & 8 \\
\hline $2006-07$ & 19 & 13.5 & 6.8 & 7 & 7.8 & 6.5 \\
\hline $2007-08$ & 15.3 & 13.7 & 3.7 & 7.2 & 12 & 6.5 \\
\hline 2008-09 & 9.6 & 14 & 1.7 & 5.5 & 20.8 & 11 \\
\hline 2009-10 & 12.5 & - & 3.8 & 3.3 & 11.7 & 9 \\
\hline
\end{tabular}


its growth rate and discount rate from 1992 January to 2010 December. An increase in interest rate discourages credit and it leads to a decline in investment in the economy, which slows down the economic activities. Discount rate shows an initial increase upto 1998 and then follows a declining trend till 2005 and then it shows a gradual increase after that. Credit to private sector shows a major decline in 2005 with an increase in discount rate and then growth rate of credit to private sector mainly remains negative which is showing the squeeze of private sector and that is the period when growth rate of GDP also start falling and prices start increasing.

From the above table and figure, it is clear that credit to private sector is directly related to growth rate of GDP. SBP is following tight monetary policy since 2005 to curb the inflationary spiral, but it discourages the credit to private sector, which slows down the economic activities in the economy and puts pressure on prices. Thus, prices go higher unbridled even after the tightening of monetary policy in Pakistan.

\section{Methodology and Data}

Let, vector $\mathrm{Yt}(\mathrm{M} \times 1)$ determines the dynamic of economy by assuming $\mathrm{M}$ small number of observable economic variables. However, further economic data that is not included in the model may be relevant for the dynamics of $\mathrm{Y}_{\mathrm{t}}$. Assume a vector $\mathrm{X}_{\mathrm{t}}(\mathrm{N} \times 1)$ consists of a large number of stationary variables and $\mathrm{Y}_{t}$ is a subset of $\mathrm{X}_{t}$. Let $\mathrm{K}$ is a small number of unobserved factors $F_{t}(K \times 1)$, obtained by compressing $\mathrm{X}_{\mathrm{t}}$. Following transition equation can be represented by joint dynamics of $F_{t}$ and $Y_{t}$ as:

$\Phi^{*}(\mathrm{~L})\left[\begin{array}{l}\mathrm{F}_{\mathrm{t}} \\ \mathrm{Y}_{\mathrm{t}}\end{array}\right]=\mathrm{U}_{\mathrm{t}}$

Where, $\Phi^{*}(\mathrm{~L})=\mathrm{I}-\Phi(\mathrm{L}), \Phi(\mathrm{L})=\Phi_{1} \mathrm{~L}+\cdots+\Phi_{\mathrm{p}} \mathrm{L}^{\mathrm{p}}$ is a matrix of conformable lag polynomial of finite order $\mathrm{p}$ in the lag operator $\mathrm{L}, \Phi_{\mathrm{j}}(\mathrm{j}=1,2, \ldots \mathrm{p})$, is a $((\mathrm{K}+\mathrm{M}) \times(\mathrm{K}+\mathrm{M}))$ matrix of coefficients and $U_{t}$ is $((K+M) \times 1)$ vector of error term with mean zero and covariance matrix $\Sigma_{\mathrm{U}}$. Bernanke et al. (2005) interpreted the unobserved factors as diffuse concepts such as economic activity or credit conditions that are represented by a large number of economic series $\mathrm{X}_{\mathrm{t}}$ and termed equation (1) as FAVAR model. Due to unobservable factors $\mathrm{F}_{\mathrm{t}}$, equation (1) cannot be estimated directly. Dynamics of the economy are explained by observable variable $\mathrm{Y}_{t}$ and common forces such as factors $F_{t}$. Following observation equation depicts the association among observed variables $\mathrm{Y}_{\mathrm{t}}$, unobservable factors $\mathrm{F}_{\mathrm{t}}$, and $\mathrm{X}_{\mathrm{t}}$ as:

$\mathrm{X}_{\mathrm{t}}=\Lambda^{\mathrm{f}} \mathrm{F}_{\mathrm{t}}+\Lambda^{\mathrm{y}} \mathrm{Y}_{\mathrm{t}}+\mathrm{E}_{\mathrm{t}}$

Where, $\mathrm{K}+\mathrm{M}<<\mathrm{N}, \mathrm{F}_{\mathrm{t}}$ is a $\mathrm{K} \times 1$ vector containing $\mathrm{K}$ unobserved factors, $\Lambda^{\mathrm{f}}$ is a $\mathrm{N} \times \mathrm{K}$ matrix of factor loadings, $\Lambda^{y}$ is a $N \times M$ matrix of coefficients and $E_{t}$ is a $N \times 1$ vector of error terms with mean zero and covariance matrix $\Sigma_{\mathrm{E}}$ which are weakly correlated. Equation (2) depicts that both $\mathrm{Y}_{\mathrm{t}}$ and $\mathrm{F}_{\mathrm{t}}$ represent forces that drive the common dynamics of $\mathrm{X}_{\mathrm{t}}$.

Equation (1) can be estimated as a standard VAR if $\mathrm{F}_{\mathrm{t}}$ is observed, but this is not possible because factors $\mathrm{F}_{\mathrm{t}}$ are unobservable (Hamilton, 1994; Lutkepohl, 2005). Two step principal component procedure of Bernanke et al. (2005) is followed to estimate the FAVAR model equation (1) and (2). This method provides a nonparametric way of uncovering the space spanned by the common components $\mathrm{C}_{\mathrm{t}}=\left(\mathrm{F}_{\mathrm{t}}, \mathrm{Y}_{\mathrm{t}}\right)$ in equation (2). Another attribute of principal components is that it deals with irregularities of data, that is, $\mathrm{X}_{\mathrm{t}}$ might include both quarterly and monthly series as well as series that have discontinued or have missing values (Bernanke and Boivin, 2003).

First $\mathrm{K}+\mathrm{M}$ principal components of $\mathrm{X}_{\mathrm{t}}$ are used to estimate the common components $\mathrm{C}_{\mathrm{t}}$ in the first step, however, $\mathrm{Yt}$ is not considered in this step. $\hat{\mathrm{F}}_{\mathrm{t}}$ is acquired as the part of space which is not covered by $\mathrm{Y}_{t}$ but covered by $\hat{C}_{t}$. Ordinary least squares (OLS) is used to estimate FAVAR equation (1) by replacing $F_{t}$ with $\hat{F}_{t}$ in the second step. It allows the idiosyncratic error term $\mathrm{E}_{\mathrm{t}}$ for some degree of cross correlation by imposing the distributional assumption (Stock and Watson, 2002). It is essential to estimate the standard errors using bootstrap procedure to obtain accurate confidence intervals on the impulse response because factors are unobservable and we are using estimated factors. Kilian (1998) bootstrap procedure is used to account for ambiguity in the factors estimation.

This study uses discount rate as the monetary policy instrument. Discount rate is the officially announced instrument of monetary policy in Pakistan. Even 
though, there is not much variation in it, but at monthly frequency, it has sufficient variation to capture the dynamics of the monetary policy in Pakistan. Therefore, innovation in the discount rate can be interpreted as monetary policy shocks. Monetary policy shocks are identified by recursive procedure, all the factors entering equation (1) respond with a lag to change in the monetary policy instrument, which is ordered last in the FAVAR model.

An intermediate step is required to obtain the final estimated factors $\hat{F}_{t}$, under the recursive supposition about $\left[F_{t}, R_{t}\right]$ which will enter the FAVAR equation. Final factor $\hat{\mathrm{F}}_{\mathrm{t}}$ is obtained by removing the dependency of $\mathrm{C}\left(\mathrm{F}_{\mathrm{t}}, \mathrm{R}_{\mathrm{t}}\right)$ on $\mathrm{R}_{\mathrm{t}}$ and therefore, the procedure of Bernanke et al. (2005) is followed, that is, matrix $\mathrm{X}_{t}$ is divided into slow and fast moving variables. $\hat{\mathrm{C}}^{\star}\left(\mathrm{F}_{\mathrm{t}}\right)$ is measured as an estimate of all common components other than $\mathrm{R}_{\mathrm{t}}$ by extracting principal component from slow moving variables which are effected after lags by $\mathrm{R}_{\mathrm{t}}$. The estimated common components $\hat{\mathrm{C}}\left(\mathrm{F}_{t}, \mathrm{R}_{\mathrm{t}}\right)$ are regressed on the observed variables $R_{t}$ and the estimated slow moving factors $\hat{\mathrm{C}}^{\star}\left(\mathrm{F}_{\mathrm{t}}\right)$ as:

$\hat{\mathrm{C}}\left(\mathrm{F}_{\mathrm{t}} \mathrm{R}_{\mathrm{t}}\right)=\mathrm{b}_{\mathrm{C}^{*}} \hat{\mathrm{C}}^{*}\left(\mathrm{~F}_{\mathrm{t}}\right)+\mathrm{b}_{\mathrm{R}} \mathrm{R}_{\mathrm{t}}+\tau_{\mathrm{t}}$

$\hat{\mathrm{F}}_{\mathrm{t}} \mathrm{is}$ estimated as

$\hat{\mathrm{F}}_{\mathrm{t}}=\hat{\mathrm{C}}\left(\mathrm{F}_{\mathrm{t}}, \mathrm{R}_{\mathrm{t}}\right)-\hat{\mathrm{b}}_{\mathrm{R}} \mathrm{R}_{\mathrm{t}}$

The VAR in $\hat{F}_{t}$ and $R_{t}$ is estimated as:

$\widehat{\Psi}^{*}(\mathrm{~L})\left[\begin{array}{l}\hat{\mathrm{F}}_{\mathrm{t}} \\ \mathrm{R}_{\mathrm{t}}\end{array}\right]=\epsilon_{\mathrm{t}}$

Recursive structure is assumed to analyze the macroeconomic shocks where the factors in Equation 5 respond with a lag (i.e. do not respond within the same period - a month here) to an unanticipated shock in monetary policy. Cholesky decomposition is used for the recursive assumption (Bagliano \& Favero, 1998; Christiano et al., 1999). This study follows Chokesky decomposition and discount rate is ordered last and and treat its innovations as the policy shocks.

Bai and Ng (2002) method is used to determine the number of factors in many studies apart from other methods in the literature, however, none of these methods consider that factor will be included in the VAR model. Therefore, we have estimated the FAVAR model with five factors $(\mathrm{K}=5)$ and the results are robust to the use of more than five factors (Munir \& Qayyum, 2014). Munir and Qayyum (2014) argued that theory is consistent with FAVAR model with five factors as compared to other specifications of FAVAR model in Pakistan. Likelihood ratio (LR) test is used for lag selection in this study. However, this study uses monthly data, therefore, to include twelve lags is appropriate to encounter the problem of autocorrelation.

Dynamic effects of structural shocks on macroeconomic variable are determined by impulse response function. The impulse response of the estimated factors and the variables observed included in Yt can be computed from Equation 5 as:

$$
\begin{aligned}
& {\left[\begin{array}{c}
\hat{F}_{t} \\
R_{t}
\end{array}\right]=\left[\widehat{\Psi}^{*}(L)\right]^{-1} \epsilon_{t}=\sum_{j=0}^{\infty} \widehat{\Theta}_{j} L^{j} \epsilon_{t}} \\
& =\sum_{j=0}^{\infty} \widehat{\Theta}_{j} L^{j} \epsilon_{t}
\end{aligned}
$$

where,

$$
\sum_{j=0}^{\infty} \widehat{\Theta}_{j} L^{j}=\left[\widehat{\Psi}^{*}(L)\right]^{-1}
$$

By using the estimator of $\mathrm{X}_{\mathrm{t}}$ in equation (2)

$$
\widehat{\mathrm{X}}_{\mathrm{t}}=\widehat{\Lambda}^{\mathrm{f}} \hat{\mathrm{F}}_{\mathrm{t}}+\widehat{\Lambda}^{\mathrm{r}} \mathrm{R}_{\mathrm{t}}
$$

The impulse response function of each variable included in $\mathrm{X}_{\mathrm{t}}$ can be computed by using the equation (6) and (7) as:

$$
\widehat{\mathrm{X}}_{\mathrm{t}}=\left[\begin{array}{ll}
\widehat{\Lambda}^{\mathrm{f}} & \widehat{\Lambda}^{\mathrm{r}}
\end{array}\right]\left[\begin{array}{l}
\hat{\mathrm{F}}_{\mathrm{t}} \\
\mathrm{R}_{\mathrm{t}}
\end{array}\right]
$$

Using the equation (6), the impulse response function of each variable included in $\mathrm{X}_{\mathrm{t}}$ can be computed as:

$$
X_{t}^{I R F}=\left[\begin{array}{ll}
\widehat{\Lambda}^{f} & \widehat{\Lambda}^{r}
\end{array}\right] \sum_{j=0}^{\infty} \widehat{\Theta}_{j} \epsilon_{t-j}
$$

This study uses 115 macroeconomic variables of 
Pakistan from January 1992 to December 2010 at monthly frequency. Major sources of data include Pakistan Bureau of Statistics, State Bank of Pakistan, and International Financial Statistics (IFS). The data has been processed in the following way: Firstly, all the series are seasonally adjusted. Secondly, it is assumed that all the variables included in $\mathrm{X}_{\mathrm{t}}$ are stationary, therefore all the variables are subject to unit root test and non-stationary series have been made stationary by taking their first or second difference. Appendix provides the description of the series and the transformation applied to the series.

\section{Results}

Impulse response function shows a $50 \mathrm{bp}$ positive shock in monetary policy (i.e. discount rate) and its impact on money and credit with 90 percent confidence interval based on Kilian (1998). Under money, the following forms of money are considered: M0: Reserve Money, M1: Narrow Money, and M2: Broad Money, while in credit the following variables are considered: Credit to Public Sector Enterprises (CPSE), and Credit to Private Sector (CPS).

Figure 2 shows that after a positive shock in interest rate M0: Reserve Money does not show any significant response. M1: Narrow Money does not show any significant response after a positive shock in interest rate. However, M2: Broad Money shows declining trend after a positive shock in monetary policy, reach its minimum in 26 months and start reviving after 34 months. Figure 3 shows that after a positive shock in interest rate Credit to Public Sector Enterprises shows a declining trend after the shock, reaches its minimum in 24 months and shows a revival after 38 months. Credit to Private Sector shows a declining trend after the tightening of monetary policy, reach its minimum in 28 months and shows revival after 36 months. However, the magnitude of decline of Credit to Private Sector is almost double than the magnitude of decline in Credit to Public Sector Enterprises (Figure 3).

M0 and M1 are not affected by monetary policy, while M2 is a good intermediate target of monetary policy in Pakistan. An increase or decrease in interest rate effect M2 inversely, hence monetary policy is achieving its goals. The question remains if monetary policy is achieving its intermediate target then what's wrong with its final targeted variables i.e. stable growth and price stability and why with the tightening of monetary policy inflation is out of control and economy has moved into the state of stagflation. One reason could be that credit to private sector is affected more than M2 after the tightening of monetary policy. The private sector is squeezing with the increase in interest rate, therefore economic activities are declining and the demand is not meeting the supply. So, all the pressure is borne by the prices to meet the demand and growth is declining persistently. The other reason could be that fiscal sector is not responding to the tightening of monetary policy, fiscal policy and monetary policy are not harmonizing and this scenario is pushing the economy into the state of stagflation. Credit channel is an important channel of monetary policy transmission mechanism in Pakistan (Agha et al., 2005; Alam \& Waheed, 2006). Monetary authorities should consider the importance of private sector in the economy and the policy should be made that does not affect the credit needs of the private sector. If private sector did not flourish in the economy, then the economy will not break out of the state of stagflation (Amjad et al., 2011).

Based on the above results, we can say that the effects of monetary policy are heterogeneous on money and credit. M0 and M1 do not show any significant response with a positive shock in monetary policy, while M2 and credit to public sector enterprises decreases with a positive shock in discount rate but start reviving later. Credit to private sector is the worst victim of monetary policy in Pakistan because it decreases more than M2 after an increase in interest rate. Monetary policy inversely effects credit to private sector, which is the engine of growth in developing countries. An increase in discount rate encourages private sector to reduce investments, which eventually causes production and employment to decline. Amjad et al. (2011) also argued that one of the major reason of stagflation in Pakistan is tight monetary policy resulted in squeeze of private sector.

\subsection{Variance Decomposition of Money and Credit}

Table 2 shows the variance decomposition of M0, M1, M2, credit to public sector enterprises and credit to private sector. Columns two to four of the table report the contribution of a shock in monetary policy to the variance of the forecast error of each 

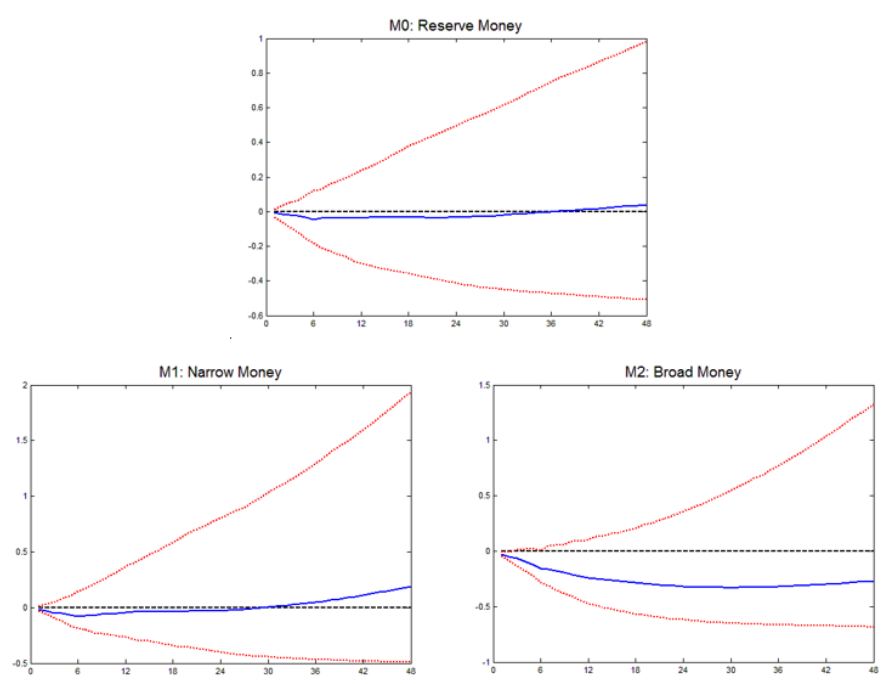

Figure 2. Impulse response of a 50bp positive shock in discount rate on Money (M0, M1 and M2).
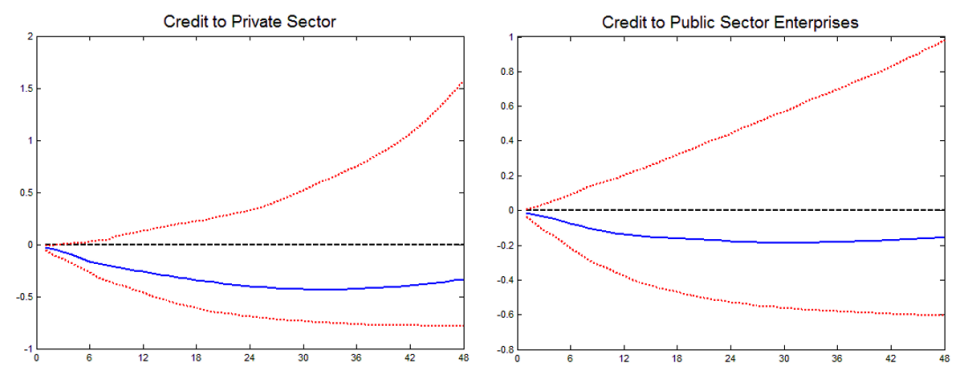

Figure 3. Impulse response of a 50bp positive shock in discount rate on Credit (CPSE, CPS). 
Table 2. Forecast Error Variance of Money and Credit Explained by the Monetary Policy Shock

Variable
Variance Decomposition

$\mathbf{R}^{2}$

\begin{tabular}{lcccc} 
& 3 months & 6 months & 18 months & \\
\hline M0: Reserve Money & 0.0361 & 0.0367 & 0.1725 & 0.0109 \\
M1: Narrow Money & 0.0868 & 0.0987 & 0.1044 & 0.0429 \\
M2: Broad Money & 0.1947 & 0.2119 & 0.1254 & 0.0485 \\
$\begin{array}{l}\text { Credit to Public Sector Enter- } \\
\text { prises (CPSE) }\end{array}$ & 0.4456 & 0.4594 & 0.0208 & 0.0123 \\
$\begin{array}{l}\text { Credit to Private Sector (CPS) } \\
\text { M }\end{array}$ & 0.1195 & 0.1188 & 0.118 & 0.1543
\end{tabular}

variable at 3-month, 6-month and 18-month horizon respectively. Last column report the R2 of the regression of each variable's on the common factors $\hat{\mathrm{C}}(\mathrm{Ft}, \mathrm{Yt})$. R2 represents the goodness of fit of the estimated factors, a high R2 indicates that the common factors nicely summaries the information contained in the variable.

Table 2 shows that at 3 -month horizon the contribution of the policy shock is 3 per cent, 8 per cent, 19 per cent, 44 per cent and 11 per cent to M0, M1, M2, credit to public sector enterprises, and credit to private sector respectively. While, at 6-month horizon, the contribution of the policy shock is 3 per cent, 9 per cent, 21 per cent, 45 per cent and 11 per cent to M0, M1, M2, CPSE and CPS respectively. After 18 months, the monetary policy shock explains around 17 per cent, 10 per cent, 12 per cent, 2 per cent and 11 per cent volatility in M0, M1, M2, credit to public sector enterprises and credit to private sector respectively.

\section{Conclusion}

Pakistan economy has passed through a state in last decade where prices has been increasing and growth was persistently declining. Monetary policy has dual objectives in Pakistan i.e. stable growth and price stability. But from FY 2005-06 monetary policy remains ineffective to curb the inflation, monetary authorities followed tight monetary policy by increasing the interest rate but inflation remain in two digits and it pushed the economy into the state of stagflation. Some economists argue that there is strong existence of price puzzle in Pakistan (Javid and Munir, 2010), while other criticized monetary policy heavily to remain ineffective to control the inflation in the economy.

This study analyzes the effectiveness of monetary policy on money and credit in Pakistan by using the FAVAR approach. Result shows that M0 and M1 do not show any significant response with a positive shock in monetary policy, while M2 shows an instantaneous decline after the shock. There is strong heterogeneity among different measures of money after an unanticipated shock in monetary policy. Credit to public sector enterprises and credit to private sector both decline after the positive shock in interest rate, but credit to private sector effects more than credit to public sector enterprises and M2.

Based on the above evidences, we can conclude that credit channel is an important and significant channel of monetary policy in Pakistan. Monetary authorities must consider the importance of private sector and their demand for credit. If they ignore the needs of credit by private sector then it leads 
to a decline in growth and increase in prices that happened in Pakistan in the recent years. A tight monetary policy will not produce the required goals until the credit needs of the private sector should be considered. Private sector plays an important role in the development process of a country. In Pakistan, the adverse victim of monetary policy is credit to private sector, therefore policy should be tailored to consider the demands of credit by private sector. The policies should be made which provide the credit to private sector at a subsidized rate and the environment of investment should be promoted by the authorities in the country.

\section{References}

Agha, A. I., Ahmed, N., Mubarik, Y. A., \& Shah, H. (2005). Transmission mechanism of monetary policy in Pakistan. SBP-Research Bulletin, 1(1), $1-23$.

Ahmad, I., \& Qayyum, A. (2008). Effect of government spending and macro-economic uncertainty on private investment in services sector: Evidence from Pakistan. European Journal of Economics, Finance and Administrative Sciences, 1, 84-96.

Alam, T., \& Waheed, M. (2006). Sectoral effects of monetary policy: Evidence from Pakistan. The Pakistan Development Review, 45(4), 1103-1115.

Amjad, R., Din, M., \& Qayyum, A. (2011). Pakistan: Breaking out of stagflation into sustained growth. Lahore Journal of Economics, 16(SE), 13-30.

Bagliano, F. C., \& Favero, C. A. (1998). Measuring monetary policy with VAR models: An evaluation. European Economic Review, 42(6), 1069-1112.

Bai, J., \& Ng, S. (2002). Determining the number of factors in approximate factor models. Econometrica, 70(1), 191-221.

Bean, C. S., Larsen, J. D., \& Nikolov, K. (2002). Financial frictions and the monetary transmission mechanism: Theory, evidence and implications. European Central Bank Working Papers No. 113. Frankfurt: European Central Bank.

Bernanke, B. S. (1983). Non-monetary effects of the financial crisis in the propagation of the Great Depression. The American Economic Review, 73(3), 257-276.

Bernanke, B. S., \& Blinder, A. S. (1988). Credit, money, and aggregate demand. The American Economic Review, 78(2), 435-39.
Bernanke, B. S., \& Blinder, A. S. (1992). The federal funds rate and the channels of monetary transmission. The American Economic Review, 82(4), 901-921.

Bernanke, B. S., \& Boivin, J. (2003). Monetary policy in a data-rich environment. Journal of Monetary Economics, 50(3), 525-546

Bernanke, B. S., \& Gertler, M. (1989). Agency costs, net worth, and business fluctuations. The American Economic Review, 79(1), 14-31.

Bernanke, B. S., \& Gertler, M. (1995). Inside the black box: The credit channel of monetary policy transmission. The Journal of Economic Perspectives, 9(4), 27-48.

Bernanke, B. S., Boivin, J., \& Eliasz, P. S. (2005). Measuring the effects of monetary policy: A factoraugmented vector autoregressive (FAVAR) approach. The Quarterly Journal of Economics, 120(1), 387-422.

Bernanke, B. S., Gertler, M., \& Gilchrist, S. (1999). The financial accelerator in a quantitative business cycle framework. In J. B. Taylor \& M. Woodford (Eds.), Handbook of Macroeconomics (pp. 13411393). Elsevier.

Blaes, B. (2009). Money and monetary policy transmission in the Euro area: Evidence from FAVAR and VAR approaches. Deutsche Bundesbank Discussion Paper no. 18. Frankfurt: Deutsche Bundesbank.

Blinder, A. S., \& Stiglitz, J. E. (1983). Money, credit constraints, and economic cctivity. The American Economic Review, 73(2), 297-302.

Christiano, L. J., Eichenbaum, M., \& Evans, C. L. (1999). Monetary policy shocks: what have we learned and to what end? In J. B. Taylor \& M. Woodford (Eds.), Handbook of Macroeconomics (pp. 65-148). Elsevier.

Gertler, M., \& Gilchrist, S. (1993). The role of credit market imperfections in the monetary transmission mechanism: Arguments and evidence. The Scandinavian Journal of Economics, 95(1), 43-64.

Greenwald, B. C., \& Stiglitz, J. E. (1993). Financial market imperfections and business cycles. The Quarterly Journal of Economics, 108(1), 77-114.

Hamilton, J. D. (1994), Time Series Analysis. Princeton University Press.

Ireland, P. N. (2005). The Monetary Transmission Mechanism. Federal Reserve Bank of Boston Working Papers No. 06. Boston: Federal Reserve Bank of Boston.

Javid, M., \& Munir, K. (2010). The price puzzle and monetary policy transmission mechanism in Pak- 
istan: Structural vector autoregressive approach. The Pakistan Development Review, 49(4), 449-460.

Kabundi, A., \& Ngwenya, N. (2011). Assessing monetary policy in South Africa in a data-rich environment. South African Journal of Economics, 79(1), 91-107.

Kamin, S., Turner, P., \& Dack, J. V. (1998). The transmission of monetary policy. Bank for International Settlements Policy Paper No. 3. Basel: Bank for International Settlements.

Kashyap, A. K., \& Stein, J. C. (1994). Monetary policy and bank lending. In N. G. Mankiw (Ed.), Monetary policy (pp. 221-261). University of Chicago Press.

Kilian, L. (1998). Small-sample confidence intervals for impulse response functions. The Review of Economics and Statistics, 80(2), 218-230.

Kiyotaki, N., \& Moore, J. (1997). Credit cycles. Journal of Political Economy, 105(2), 211-248.

Kuttner, K. N., \& Mosser, P. C. (2002). The Monetary transmission mechanism: Some answers and further questions. Federal Reserve Bank of New York Economic Policy Review, 8(1), 15-26.

Lagana, G., \& Mountford, A. (2005). Measuring monetary policy in the U.K.: A factor-augmented vector autoregression model approach. The Manchester School, 73(SE), 77-98.

Lutkepohl, H. (2005). New introduction to multiple time series analysis. Springer-Verlag.

Mishkin, F. S. (1995). Symposium on the monetary transmission mechanism. The Journal of Economic Perspectives, 9(4), 3-10.

Munir, K. (2018). Dynamic effects of monetary policy on output and prices in Pakistan: A Disaggregate Analysis. Journal of the Asia Pacific Economy, 23(1), 99-118.

Munir, K., \& Qayyum, A. (2014). Measuring the effects of monetary policy in Pakistan: A factor augmented vector autoregressive approach. Empirical Economics, 46(3), 843-864.

Roosa, R. V. (1951). Interest rates and the Central Bank. In H. G. Johnson, (Ed.), Money, trade, and economic growth: Essays in honor of John Henry Williams (pp. 270-295). Macmillan.

SBP. (2002). Pakistan: Financial sector assessment 19902000. State Bank of Pakistan.

Senbet, D. (2008). Measuring the impact and international transmission of monetary policy: A factor-augmented vector autoregressive (FAVAR) approach. European Journal of Economics, Finance and Administrative Sciences, 13, 121-143.

Shibamoto, M. (2007). An analysis of monetary policy shocks In Japan: A factor augmented vector autoregressive approach. The Japanese Economic Review, 58(4), 484-503.

Sims, C. A. (1980). Macroeconomics and reality. Econometrica, 48(1), 1-48.

Sims, C. A. (1992). Interpreting the macroeconomic time series facts: The effects of monetary policy. European Economic Review, 36(5), 975-1000.

Soares, R. (2011). Assessing monetary policy in the Euro area: a Factor-Augmented VAR Approach (Banco de Portugal Working Paper No. 11), Lisbon: Banco de Portugal.

Stock, J. H., \& Watson, M. W. (2002). Macroeconomic forecasting using diffusion indexes. Journal of Business \& Economic Statistics, 20(2), 147-162. 


\section{Appendix}

The data listed below describe the complete description of the variable, define whether it is considered slow or fast moving variables, and the transformation applied to the series to make it stationary. Below are the numerical codes for the transformations performed on the data:
1: No transformation;

2: Log transformation;

3: First difference;

4: First difference of log

Table 3. Description of Data

\begin{tabular}{|c|c|c|c|c|}
\hline S.No & $\begin{array}{l}\text { Variable } \\
\text { Output }\end{array}$ & Transformation & Fast/Slow & Detail of Variable \\
\hline 1 & IPI & 2 & SLOW & $\begin{array}{l}\text { Industrial Production Index (SA) } \\
\text { (Base: 1999-2000) }\end{array}$ \\
\hline 2 & IPVP & 1 & SLOW & $\begin{array}{l}\text { Production Index of Vegetable Products (SA) } \\
\text { (Base: 1999-2000) }\end{array}$ \\
\hline 3 & IPTB & 1 & SLOW & $\begin{array}{l}\text { Production Index of Tea Blended (SA) } \\
\text { (Base: 1999-2000) }\end{array}$ \\
\hline 4 & IPJG & 1 & SLOW & $\begin{array}{l}\text { Production Index of Jute Goods (SA) } \\
\text { (Base: 1999-2000) }\end{array}$ \\
\hline 5 & IPPB & 2 & SLOW & $\begin{array}{l}\text { Production Index of Paper and Board (SA) } \\
\text { (Base: 1999-2000) }\end{array}$ \\
\hline 6 & IPFL & 2 & SLOW & $\begin{array}{l}\text { Production Index of Fertilizers (SA) } \\
\text { (Base: 1999-2000) }\end{array}$ \\
\hline 7 & IPAM & 4 & SLOW & $\begin{array}{l}\text { Production Index of Auto-mobiles (SA) (Base: } \\
\qquad 1999-2000)\end{array}$ \\
\hline 8 & PVG & 4 & SLOW & Production of Vegetable Ghee (SA) \\
\hline 9 & PSG & 1 & SLOW & Production of Sugar (NSA) \\
\hline 10 & PCGR & 1 & SLOW & Production of Cigarettes (SA) \\
\hline 11 & $\mathrm{PCY}$ & 4 & SLOW & Production of Cotton Yarn (SA) \\
\hline 12 & PCC & 4 & SLOW & Production of Cotton Cloth (SA) \\
\hline 13 & PPR & 4 & SLOW & Production of Paper (SA) \\
\hline 14 & PPB & 4 & SLOW & Production of Paper Board (SA) \\
\hline
\end{tabular}


Table 3. Description of Data (Continued)

\begin{tabular}{|c|c|c|c|c|}
\hline S.No & $\begin{array}{c}\text { Variable } \\
\text { Output }\end{array}$ & Transformation & Fast/Slow & Detail of Variable \\
\hline 15 & PSDA & 1 & SLOW & Production of Soda Ash (SA) \\
\hline 16 & PCS & 4 & SLOW & Production of Caustic Soda (SA) \\
\hline 17 & PSUA & 4 & SLOW & Production of Sulphuric Acid (SA) \\
\hline 18 & PCHG & 1 & SLOW & Production of Chlorine Gas (SA) \\
\hline 19 & PUR & 1 & SLOW & Production of Urea (SA) \\
\hline 20 & PSP & 1 & SLOW & Production of Super Phosphate (NSA) \\
\hline 21 & PAN & 1 & SLOW & Production of Ammonium Nitrate (SA) \\
\hline 22 & PNP & 1 & SLOW & Production of Nitro Phosphate (SA) \\
\hline 23 & PCTT & 4 & SLOW & Production of Cycles Tyres and Tubes (SA) \\
\hline 24 & PMTT & 4 & SLOW & Production of Motor Tyre and Tubes (SA) \\
\hline 25 & PCMN & 4 & SLOW & Production of Cement (SA) \\
\hline 26 & PPI & 1 & SLOW & Production of Pig Iron (SA) \\
\hline 27 & PTR & 1 & SLOW & Production of Tractors (SA) \\
\hline 28 & PBC & 1 & SLOW & Production of Bicycle (SA) \\
\hline 29 & PSS & 1 & SLOW & Production of Silica Sand (SA) \\
\hline 30 & PGPS & 2 & SLOW & Production of Gypsum (SA) \\
\hline 31 & PLST & 4 & SLOW & Production of Lime Stone (SA) \\
\hline 32 & PRST & 1 & SLOW & Production of Rock Salt (SA) \\
\hline 33 & PCOL & 1 & SLOW & Production of Coal (SA) \\
\hline 34 & PCHCL & 1 & SLOW & Production of China Clay (SA) \\
\hline 35 & PCHM & 1 & SLOW & Production of Chromite (SA) \\
\hline 36 & PCRO & 4 & SLOW & Production of Crude Oil (SA) \\
\hline
\end{tabular}


Table 3. Description of Data (Continued)

\begin{tabular}{|c|c|c|c|c|}
\hline S.No & $\begin{array}{l}\text { Variable } \\
\text { Output }\end{array}$ & Transformation & Fast/Slow & Detail of Variable \\
\hline 37 & PNGS & 4 & SLOW & Production of Natural Gas (SA) \\
\hline 38 & PELC & 4 & SLOW & Production of Electricity (SA) \\
\hline S.No & $\begin{array}{l}\text { Variable } \\
\text { Prices }\end{array}$ & Transformation & Fast/Slow & Detail of Variable \\
\hline 39 & CPIG & 4 & SLOW & $\begin{array}{l}\text { CPI: General (SA) } \\
\text { (Base:2000-2001) }\end{array}$ \\
\hline 40 & CPIFBT & 4 & SLOW & $\begin{array}{l}\text { CPI: Food Beverages and Tobacco (SA) } \\
\text { (Base:2000-2001) }\end{array}$ \\
\hline 41 & CPIAPF & 4 & SLOW & $\begin{array}{l}\text { CPI: Apparel textile and Footwear (SA) } \\
\text { (Base:2000-2001) }\end{array}$ \\
\hline 42 & CPIHR & 2 & SLOW & $\begin{array}{l}\text { CPI: House Rent (SA) } \\
\text { (Base:2000-2001) }\end{array}$ \\
\hline 43 & CPIFL & 4 & SLOW & $\begin{array}{l}\text { CPI: Fuel and Lighting (SA) } \\
\text { (Base:2000-2001) }\end{array}$ \\
\hline 44 & CPIHFFE & 4 & SLOW & $\begin{array}{l}\text { CPI: Household Furniture and Equipment (SA) } \\
\text { (Base:2000-2001) }\end{array}$ \\
\hline 45 & CPITC & 2 & SLOW & $\begin{array}{l}\text { CPI:Transportation and Communication (SA) } \\
\text { (Base:2000-2001) }\end{array}$ \\
\hline 46 & CPIRE & 4 & SLOW & $\begin{array}{l}\text { CPI: Recreation and Entertainment (SA) } \\
\text { (Base:2000-2001) }\end{array}$ \\
\hline 47 & CPICLPA & 4 & SLOW & $\begin{array}{l}\text { CPI: Cleaning Laundry and Personal Appearance } \\
\text { (SA) (Base:2000-2001) }\end{array}$ \\
\hline 48 & WPIG & 4 & SLOW & $\begin{array}{l}\text { WPI: General (SA) } \\
\text { (Base:2000-2001) }\end{array}$ \\
\hline 49 & WPIF & 4 & SLOW & $\begin{array}{l}\text { WPI: Food (SA) } \\
\text { (Base:2000-2001) }\end{array}$ \\
\hline 50 & WPIRM & 4 & SLOW & $\begin{array}{l}\text { WPI: Raw Material (SA) } \\
\text { (Base:2000-2001) }\end{array}$ \\
\hline
\end{tabular}


Table 3. Description of Data (Continued)

\begin{tabular}{|c|c|c|c|c|}
\hline S.No & $\begin{array}{l}\text { Variable } \\
\text { Prices }\end{array}$ & Transformation & Fast/Slow & Detail of Variable \\
\hline 51 & WPIFLL & 2 & SLOW & $\begin{array}{l}\text { WPI: Fuel, Lighting and Lubricants (SA) } \\
\text { (Base:2000-2001) }\end{array}$ \\
\hline 52 & WPIM & 4 & SLOW & $\begin{array}{l}\text { WPI: Manufacturers (SA) } \\
\text { (Base:2000-2001) }\end{array}$ \\
\hline 53 & WPIBM & 4 & SLOW & $\begin{array}{l}\text { WPI: Building Materials (SA) } \\
\text { (Base:2000-2001) }\end{array}$ \\
\hline S.No & $\begin{array}{l}\text { Capital } \\
\text { Market }\end{array}$ & Transformation & Fast/Slow & Detail of Variable \\
\hline 54 & GIG & 4 & FAST & $\begin{array}{l}\text { SBGI: General (SA) } \\
\text { (Base:2000-2001) }\end{array}$ \\
\hline 55 & GICOT & 4 & FAST & $\begin{array}{l}\text { SBGI: Cotton and Other Textiles (SA) } \\
\text { (Base:2000-2001) }\end{array}$ \\
\hline 56 & GITS & 4 & FAST & $\begin{array}{c}\text { SBGI: Textile Spinning (SA) } \\
\text { (Base:2000-2001) }\end{array}$ \\
\hline 57 & GITWC & 1 & FAST & $\begin{array}{l}\text { SBGI: Textile Weaving and Composite (SA) } \\
\text { (Base:2000-2001) }\end{array}$ \\
\hline 58 & GIOT & 4 & FAST & $\begin{array}{l}\text { SBGI: Other textiles (SA) } \\
\text { (Base:2000-2001) }\end{array}$ \\
\hline 59 & GICOP & 4 & FAST & $\begin{array}{l}\text { SBGI: Chemical and other Pharmaceuticals(SA) } \\
\text { (Base:2000-2001) }\end{array}$ \\
\hline 60 & GIE & 1 & FAST & $\begin{array}{l}\text { SBGI: Engineering (SA) } \\
\quad \text { (Base:2000-2001) }\end{array}$ \\
\hline 61 & GIAA & 4 & FAST & $\begin{array}{l}\text { SBGI: Auto and Allied (SA) } \\
\text { (Base:2000-2001) }\end{array}$ \\
\hline 62 & GICEG & 4 & FAST & $\begin{array}{l}\text { SBGI: Cables and Electric Goods (SA) } \\
\text { (Base:2000-2001) }\end{array}$ \\
\hline 63 & GISA & 4 & FAST & $\begin{array}{l}\text { SBGI: Sugar and Allied(SA) } \\
\text { (Base:2000-2001) }\end{array}$ \\
\hline
\end{tabular}


Table 3. Description of Data (Continued)

\begin{tabular}{|c|c|c|c|c|}
\hline S.No & $\begin{array}{l}\text { Capital } \\
\text { Market }\end{array}$ & Transformation & Fast/Slow & Detail of Variable \\
\hline 64 & GIPB & 4 & FAST & $\begin{array}{l}\text { SBGI: Paper and Board (SA) } \\
\text { (Base:2000-2001) }\end{array}$ \\
\hline 65 & GIC & 4 & FAST & $\begin{array}{l}\text { SBGI: Cement (SA) } \\
\text { (Base:2000-2001) }\end{array}$ \\
\hline 66 & GIFE & 4 & FAST & $\begin{array}{l}\text { SBGI: Fuel and Energy (SA) } \\
\text { (Base:2000-2001) }\end{array}$ \\
\hline 67 & GITC & 1 & FAST & $\begin{array}{l}\text { SBGI: Transport and Communication (SA) } \\
\text { (Base:2000-2001) }\end{array}$ \\
\hline 68 & GIBOFI & 4 & FAST & $\begin{array}{l}\text { SBGI: Banks and Other Financial Institutions(SA) } \\
\text { (Base:2000-2001) }\end{array}$ \\
\hline 69 & GIBIC & 4 & FAST & $\begin{array}{l}\text { SBGI: Banks and Investment Companies (SA) } \\
\text { (Base:2000-2001) }\end{array}$ \\
\hline 70 & GIMD & 1 & FAST & $\begin{array}{l}\text { SBGI: Modarabas (SA) } \\
\text { (Base:2000-2001) }\end{array}$ \\
\hline 71 & GILC & 4 & FAST & $\begin{array}{l}\text { SBGI: Leasing Companies (SA) } \\
\text { (Base:2000-2001) }\end{array}$ \\
\hline 72 & GII & 1 & FAST & $\begin{array}{l}\text { SBGI: Insurance (SA) } \\
\text { (Base:2000-2001) }\end{array}$ \\
\hline 73 & GIMQ & 4 & FAST & $\begin{array}{l}\text { SBGI: Miscellaneous (SA) } \\
\text { (Base:2000-2001) }\end{array}$ \\
\hline 74 & GIJ & 4 & FAST & $\begin{array}{c}\text { SBGI: Jute (SA) } \\
\text { (Base:2000-2001) }\end{array}$ \\
\hline 75 & GIFA & 4 & FAST & $\begin{array}{l}\text { SBGI: Food and Allied (SA) } \\
\text { (Base:2000-2001) }\end{array}$ \\
\hline 76 & GIGC & 4 & FAST & $\begin{array}{l}\text { SBGI: Glass and Ceramics (SA) } \\
\text { (Base:2000-2001) }\end{array}$ \\
\hline 77 & GIVA & 4 & FAST & $\begin{array}{l}\text { SBGI: Vanaspati and Allied (SA) } \\
\text { (Base:2000-2001) }\end{array}$ \\
\hline
\end{tabular}


Table 3. Description of Data (Continued)

\begin{tabular}{|c|c|c|c|c|}
\hline S.No & $\begin{array}{l}\text { Capital } \\
\text { Market }\end{array}$ & Transformation & Fast/Slow & Detail of Variable \\
\hline 78 & $\mathrm{GIO}$ & 4 & FAST & $\begin{array}{l}\text { SBGI: Others (SA) } \\
\text { (Base:2000-2001) }\end{array}$ \\
\hline 79 & SIG & 4 & FAST & $\begin{array}{l}\text { SBSI: General (SA) } \\
\text { (Base:2000-2001) }\end{array}$ \\
\hline 80 & SICOT & 4 & FAST & $\begin{array}{l}\text { SBSI: Cotton and Other Textiles (SA) } \\
\text { (Base:2000-2001) }\end{array}$ \\
\hline 81 & SICOP & 4 & FAST & $\begin{array}{l}\text { SBSI: Chemical and other Pharmaceuticals (SA) } \\
\qquad \text { (Base:2000-2001) }\end{array}$ \\
\hline 82 & SIE & 4 & FAST & $\begin{array}{l}\text { SSBSI: Engineering (SA) } \\
\quad(\text { Base:2000-2001) }\end{array}$ \\
\hline 83 & SIAA & 4 & FAST & $\begin{array}{l}\text { SBSI: Auto and Allied (SA) } \\
\text { (Base:2000-2001) }\end{array}$ \\
\hline 84 & SICEG & 1 & FAST & $\begin{array}{l}\text { SBSI: Cables and Electric Goods (SA) } \\
\qquad \text { (Base:2000-2001) }\end{array}$ \\
\hline 85 & SISA & 4 & FAST & $\begin{array}{l}\text { SBSI: Sugar and Allied (SA) } \\
\quad \text { (Base:2000-2001) }\end{array}$ \\
\hline 86 & SIPB & 4 & FAST & $\begin{array}{l}\text { SBSI: Paper and Board (SA) } \\
\quad \text { (Base:2000-2001) }\end{array}$ \\
\hline 87 & SIC & 1 & FAST & $\begin{array}{l}\text { SBSI: Cement (SA) } \\
\text { (Base:2000-2001) }\end{array}$ \\
\hline 88 & SIFE & 4 & FAST & $\begin{array}{l}\text { SBSI: Fuel and Energy (SA) } \\
\text { (Base:2000-2001) }\end{array}$ \\
\hline 89 & SITC & 4 & FAST & $\begin{array}{l}\text { SBSI: Transport and Communication (SA) } \\
\text { (Base:2000-2001) }\end{array}$ \\
\hline 90 & SIBOFI & 4 & FAST & $\begin{array}{l}\text { SBSI: Banks and Other Financial Institutions(SA) } \\
\text { (Base:2000-2001) }\end{array}$ \\
\hline 91 & SIMQ & 4 & FAST & $\begin{array}{l}\text { SBSI: Miscellaneous (SA) } \\
\text { (Base:2000-2001) }\end{array}$ \\
\hline
\end{tabular}


Table 3. Description of Data (Continued)

\begin{tabular}{|c|c|c|c|c|}
\hline S.No & $\begin{array}{c}\text { Interest } \\
\text { Rate }\end{array}$ & Transformation & Fast/Slow & Detail of Variable \\
\hline 92 & DISR & 1 & FAST & Discount rate (NSA) \\
\hline 93 & CMR & 2 & FAST & Call money Rate (NSA) \\
\hline 94 & GTB6m & 2 & FAST & 6-month Govt. Treasury Bill Rate (NSA) \\
\hline 95 & GBY & 2 & FAST & Govt. Bond Yield (NSA) \\
\hline S.No & $\begin{array}{c}\text { Money \& } \\
\text { Credit }\end{array}$ & Transformation & Fast/Slow & Detail of Variable \\
\hline 96 & Mo & 4 & FAST & M0 : Reserve Money (SA) \\
\hline 97 & M1 & 4 & FAST & M1 : Narrow Money (SA) \\
\hline 98 & M2 & 4 & FAST & M2 : Broad Money (SA) \\
\hline 99 & CPSE & 4 & FAST & Credit to Public Sector Enterprises (SA) \\
\hline 100 & CPS & 4 & FAST & Credit to Private Sector (SA) \\
\hline S.No & $\begin{array}{c}\text { External } \\
\text { Sector }\end{array}$ & Transformation & Fast/Slow & Detail of Variable \\
\hline 101 & EXRUSA & 4 & FAST & Exchange Rate USA, Rs/\$ (NSA) \\
\hline 102 & NEER & 4 & FAST & Nominal Effective Exchange Rate (NSA) \\
\hline 103 & REER & 1 & FAST & Real Effective Exchange Rate (NSA) \\
\hline 104 & RSDRH & 2 & FAST & (Base:2005) \\
\hline 105 & RFEX & 4 & FAST & Reserve: SDR Holding (SA) \\
\hline 106 & RGLD & 4 & FAST & Reserve: Foreign Exchange (SA) \\
\hline 107 & ITI & 4 & SLOW & Reserve: Gold (SA) \\
\hline 108 & ICNM & 4 & SLOW & Total Imports (SA) \\
\hline 109 & IRMCNG & 2 & SLOW & Imports of Raw material Consumer Goods (SA) \\
\hline 110 & IRMCPG & 4 & SLOW & Imports of Raw material Capital Goods (SA) \\
\hline
\end{tabular}


Table 3. Description of Data (Continued)

\begin{tabular}{ccccc} 
S.No & $\begin{array}{c}\text { External } \\
\text { Sector }\end{array}$ & Transformation & Fast/Slow & Detail of Variable \\
\hline 111 & ICPG & 4 & SLOW & Imports of Capital Goods (SA) \\
112 & ETE & 2 & SLOW & Total Exports (SA) \\
113 & EPRC & 2 & SLOW & Export of Primary Commodities (SA) \\
114 & ESM & 4 & SLOW & Export of Semi Manufactures (SA) \\
115 & EMG & 2 & SLOW & Export of Manufactured Goods (SA) \\
\hline
\end{tabular}

